\title{
In the Covid-19 Pandemic, How Well did Zoom Cloud Meeting and Quizizz Media Perform?
}

\author{
Ade Vitarani' ${ }^{1}$ Pratiwi Pujiastuti², Anang Sudigdo3
}

DOI: 10.35445/alishlah.v13i3.663

\begin{tabular}{|c|c|}
\hline Article Info & Abstract \\
\hline $\begin{array}{l}\text { Key words: } \\
\text { Zoom Cloud Meeting; } \\
\text { Quizizz; } \\
\text { Interest in Learning }\end{array}$ & $\begin{array}{l}\text { The purpose of this study was to investigate whether or not the use of Zoom } \\
\text { Cloud Meeting and Quiziz media had a substantial impact on students' interest } \\
\text { in learning about literature. The participants in this study were } 80 \text { students } \\
\text { who were enrolled in PGSD UST for the four semesters. This study is a quasi- } \\
\text { experimental study that uses a questionnaire approach called the learning } \\
\text { interest scale questionnaire to collect data with the help of the Kolmogorov- } \\
\text { Smirnov analytical approach and the } t \text {-test. Based on the findings of the t-test, } \\
\text { it was determined that } t=0.338 \text { and } p=0.563 \text { were significant. When th is } \\
\text { number was compared to a significance value of o.o5 for the one-score test, the } \\
\text { p-value was found to be more than o.o5, indicating a statistically significant } \\
\text { difference. Thus, classes taught using Zoom Cloud Meeting and Quizizz media } \\
\text { have a higher level of enthusiasm in learning than programs taught using WAG } \\
\text { medium (Whatsapp Group). }\end{array}$ \\
\hline
\end{tabular}

Kata Kunci:

Zoom Cloud Meeting;

Quizizz;

Minat Belajar

\begin{abstract}
Abstrak
Penelitian ini bertujuan untuk mengetahui pengaruh media Zoom Cloud Meeting dan Quiziz secara signifikan terhadap minat belajar sastra mahasiswa. Subyek penelitian ini adalah 80 mahasiswa semester 4 PGSD UST. Penelitian ini merupakan penelitian eksperimen semu dengan teknik angket skala minat belajar. Dengan teknik analisis Kolmogorov Smirnov dan uji t. Berdasarkan hasil uji-t diperoleh $t=0,338$ dengan $p=0,563$. Nilai ini kemudian dibandingkan dengan nilai signifikansi o,05 untuk uji one-score, dengan pvalue $=0,563>0,05$. Artinya ada perbedaan minat belajar antara kelas yang diajar menggunakan media Zoom Cloud Meeting dan Quizizz dengan kelas y ang diajar menggunakan WAG(Whatsapp Group).
\end{abstract}

\footnotetext{
${ }^{1}$ Universitas NegeriYogyakarta, Yogyakarta, Indonesia

Email: adevitarani.2020@student.uny.ac.id

${ }^{2}$ Universitas Negeri Yogyakarta, Yogyakarta, Indonesia

Email:pratiwi@uny.ac.id

3 Uiversitas Sarjanawiyata Tamansiswa, Yogyakarta, Indonesia

Email: anang.sudigdo@ustjogja.ac.id
} 


\section{INTRODUCTION}

As one of the efforts to break the chain of the spread of Covid-19, the Indonesian government has made a policy for universities to carry out distance learning activities where all students attend lectures from home (Wahyu \& Simanullang, 2020). (Belawati, 2019) explained that the distance learning system is a system that has existed since the mid 18 th century. Since the beginning, distance learning has always used technology in the implementation of learning. The term Distance Learning is contained in Law Number 20 of 2003 concerning the National Education System Article 1 which states that the learning method between teachers and learners is separate, and learning uses various learning resources through communication, information technology and when the face-to-face learning process stops but suitable learning media in these conditions must be done. (Zhang, Yixin, Annie, Yuan, \& Mario, 2020) call it a class delay but does not delay learning because learning is not in the classroom directly but through the classroom indirectly (online). Therefore, distance learning activities and online learning are the choices of various schools in Indonesia. (Irawati, 2020) mentioning distance learning also has drawbacks. This deficiency results in incomplete material received by students so that it interferes with the learning process because students' understanding is lagging.

Based on observations and interviews that have been conducted from February 25 to March 04, 2021, via Whatsapp Group in the Children's Literature lecture, it was found that from 40 students, ten students could not attend classes because the network constrained them, 10 other students said they could not understand the material well and clearly and 20 Students who tend to be passive are not interested when the lecture is carried out. This can be seen during the discussion and question and answer lectures. No one asks and thinks students are just listening. So we need a learning media that attracts students and makes students understand the material.

The implementation of children's literature lectures must have continuity between students and lecturers. If there is no continuity between students and lecturers, the course will not be optimal. In addition, there is a lack of media to evaluate students when they finish carrying out learning. There is no benchmark whether students have understood the material or not. (Inga, Anne, \& Momoko, 2021) stated that many students do not have the necessary competencies to use resources optimally. The lack of familiarization training with technical tools can increase resilience at the anticipatory stage. This is in line with (Olena \& Oksana, 2020), saying that all technological limitations unexpectedly trigger unlimited academic freedom for faculty in choosing platforms, tools and methods for using ICT in the teaching and learning process. In addition, there is a need for interactive learning facilities using internet media as a substitute for face-to-face lectures to be online, not just collecting tasks that burden students (Simamora, 2020).

One alternative media that can be used to make it easier for students to understand the material in the media is Zoom Cloud Meeting and Quizizz. (Prima \& Fitri , 2021) concluded that Zoom Cloud Meeting is one of the most widely used online applications and is an alternative to distance learning. Zoom Cloud Meeting facilitates students with features that allow students to work independently but share their thoughts through groups. This application can stimulate student involvement, motivation, and success in the learning process (Muhammad, 2021). This is in line with (Kasman \& Zohri, 2021), stating that this application is a learning modality during a pandemic because its use has proven to be significant, so it can be applied considering the benefits and efficiency help increase student interest in learning. This app is known to be relatively cheap and affordable for all, it provides its users with some of the best features and benefits, and the basic package of this application is entirely free (Serikbayeva \& Erzhanova, 2021). Most students agree and are satisfied with this application. Educators are also facilitated because they can monitor their activities through small groups (Shaid, Tasaddaq, Abdul, \& Kiran, 2021). This application lets users set a schedule to start a meeting and create a meeting through other accounts such as Gmail, 
Outlook, and iCal. Zoom Meeting has many excellent features to conduct meetings via email video conferencing (Liu, 2020).

While Quizizz is a web tool for creating interactive learning quiz games that can be used both inside and outside the classroom (Nashar, Nurhasanah, \& Fauzan, 2021), in addition, this application has game characteristics such as avatars, themes, memes, and entertaining and interesting music (Rani \& Ernawulan, 2021). According to (Nurrohmatul \& Luluk, 2021), Quizizz is accessible with multiple devices and players simultaneously. This feature makes the evaluation of distance learning more straightforward, thus indirectly helping the online learning process. In line with (Trully \& Ganefri, 2020), Quizizz is suitable for use as creative and innovative media because it is equipped with multiple choice questions and opinion questions to independently use them together. Then it can be concluded that Quizizz is a game-based application that rings multiplayer activities into the classroom and makes them fun interactive practiceclass (Leony, 2019).

Some of the results of previous research conducted by Suardi, M. (2020) on Zoom Cloud Meetings Application in the Learning Process show that the e-learning process by utilizing Zoom Cloud Meetings is quite effective to use even with a few advantages. Its flexibility so that it can be implemented anywhere makes students more relaxed in learning, not tense, and feels comfortable. Another study by Kuswandi, W. (2021) on the Quality of Distance Learning for Community Education shows that Zoom Meeting in learning and teaching activities can make it easier for teachers (lecturers) to control students. In addition, the learning materials provided by lectur ers to students can be seen and observed by students independently. Further research by Haryati et al. (2021) on the development of evaluation instruments in online learning using the Quizizz Application found that the app Quizizz make it easier for lecturers to manage evaluations. Students become motivated to get good evaluation scores, concentration when doing assessments is in the very good category and evaluation instruments with Quizizz exciting and fun for students. This is in line with the research of (Marsye , 2021) on basic training participants' perceptions of the use of Quizizz found that Quizizz is a fun learning evaluation method, efficient in terms of time and cost, and easy to use, and the results are more accurate and transparent. Until the application, Quizizz recommended widyaiswara or facilitators as well as the millennial generation.

In connection with this, experimental research was held to prove it with the media Zoom Cloud Meeting and Quizizz will help improve students' understanding of children's literature. The purpose of this research is the application of Zoom Cloud Meeting and Quizizz. This can increase student interest in learning in children's literature courses. According to (Sardiman, 2003) interest is defined as a condition that occurs when a person sees the characteristics or temporary meaning of a situation associated with his desires or needs. This was later confirmed by (Muhhibin, 2008) stating that interest is a high tendency and excitement or a great passion for something. In addition (Slameto., 2010) argues that interest is a persistent tendency to pay attention and remember some activities.

\section{METHOD}

The study used an experimental method with a quasi-experimental design type of research which was carried out to determine the influence of the media. Zoom Cloud Meeting and Quizizzon interest in learning literature for UST PGSD students during the COVID-19 pandemic. The place of this research is at PGSD UST. The population in this assessment are all students of the fourth semester of PGSD UST Class of 2019 who are taking Children's Literature courses, which are 360 students. The sample of this research is class $4 \mathrm{G}$ as the experimental group and class $4 \mathrm{H}$ as the control group. The data collection technique in this study used a questionnaire of 25 valid questions that met the requirements of a good instrument with four answer choices, namely always, often, sometimes, and never. The scores for positive statements are 4 for always, 3 for often, 2 for sometimes, and 1 for never. At the same time, the score for negative comments is 1 for 
always, 2 for often, 3 for sometimes, and 4 for never. Pre-test data and post-test data were processed using SPSS 25.0 software. The data analysis technique carried out in this study used the independent sample test. Before conducting the $\mathrm{T}$-test, the researcher had to test the prerequisites first, namely the distribution normality test and the homogeneity test of variance. Below is a table of standard curves for the experimental class and the control class.

Table1. Standard Curve Criteria for Experiment and Control Class

\begin{tabular}{cc}
\hline Interval Kelas & Kriteria \\
\hline $13,509 \leq X \leq 18,00$ & Very High \\
$10,503 \leq \bar{X} \leq 13,509$ & High \\
$7,497 \leq \bar{X} \leq 10,503$ & Medium \\
$4,491 \leq \bar{X} \leq 7,497$ & Low \\
$0 \leq \bar{X} \leq 4,491$ & Very Low \\
\hline
\end{tabular}

\section{FINDINGS AND DISCUSSION}

The research was conducted by distributing opinion questionnaires in which some questions had been validated. The questionnaires were then distributed to $4 \mathrm{G}$ and $4 \mathrm{H}$ class students who took the UST PGSD children's literature course. The purpose of this study is to find out the differences in interest in learning children's literature between classes and media Zoom Cloud Meeting and Quizizz and class with WhatsApp group (WAG) media. The scores for positive statements are 4 for always, 3 for often, 2 for sometimes, and 1 for never. At the same time, the score for negative comments is 1 for always, 2 for often, 3 for sometimes, and 4 for never. Pre-test data and post-test data were processed using SPSS 25.0 software. Based on the data processing carried out, a description of the data in the form of mean, standard deviation, range, minimum score, and the maximum score is obtained in the following table.

Tabel 2. Statistical Description Data

\begin{tabular}{lccccc}
\hline & N & Minimum & Maximum & Mean & $\begin{array}{c}\text { Std. } \\
\text { Deviation }\end{array}$ \\
\hline PreTest Eksperimen & 40 & 33 & 69 & 52.30 & 9.073 \\
PostTest Eksperimen & 40 & 67 & 94 & 81.28 & 6.831 \\
PreTest Kontrol & 40 & 25 & 59 & 44.68 & 9.382 \\
PreTest Kontrol & 40 & 36 & 66 & 51.70 & 7.603 \\
\hline
\end{tabular}

Obtain data on interest in learning. Researchers first teach literature courses child. In the experimental class using learning media Zoom Cloud Meeting and Quizizz, which was conducted four times face-to-face and one post-test, the control class used WAG (WhatsApp WhatsApp group) media, which was carried out four times face-to-face and one post-test. The researcher gave a post-test to measure the students' ability after studying the material. The posttest experimental class and control class results were then analyzed to determine the tendencies and differences in children's literature learning interests.

To find out the tendency of interest in learning children's literature by using learning media Zoom Cloud Meeting and Quizizz, 4G PGSD UST class students with a total of 40 students as the experimental class using a test question in the form of a questionnaire as many as 25 questions. While in the control class with WAG learning media. To find out the tendency of interest in learning children's literature by using WAG learning media in 4H PGSD UST class students with a total of 40 students as the control class and using test questions in the form of a questionnaire as many as 25 questions.

Based on the calculation results, the average experimental class is 81.28. The normal curve is in the very high category at the interval of $81.28 \leq 18.00$. Thus, the tendency to learn literature for experimental class students who are taught using Zoom Cloud Meeting and Quizizz Learning media is very high. While the control class obtained an average of 51.70 in the normal curve is in 
the very high category at the interval of $51.70 \leq 18.00$. Thus, the tendency of students' interest in learning literature from control class students who are taught using WAG learning media is very high. Before conducting the Independent Test, a data analysis test was carried out, namely the distribution normality test, to determine whether the distribution was normal or not. The distribution normality test in this study is calculated by the formula Kolmogorov Smirnov. The results of these calculations are seen in the following table.

Tabel 3. Tests of Normality

\begin{tabular}{llccc}
\hline & Kelas & Statistic & df & Sig \\
\hline Learning & PreTest Eksperimen & .107 & 40 & .200 \\
Interests & PostTest Eksperimen & .091 & 40 & .200 \\
& PreTest Kontrol & .121 & 40 & .144 \\
& PreTest Kontrol & .120 & 40 & .152 \\
\hline
\end{tabular}

Based on the normality test Kolmogorov Smirnov $\mathrm{Z}$ above, the following results are obtained. The experimental post-test data has a Kolmogorov Smirnov Zvalue of 0.091. In contrast, the significance value $(\mathrm{p}=0.200)$ means that $\mathrm{p}=0.200$ is greater than 0.05 so that the experimental post-test data (X2) is normally distributed. While the control post-test data has a Kolmogorov Smirnov $\mathrm{Z}$ value of 0.120 , the significance value $(\mathrm{p}=0.152)$ means that the significance value of $\mathrm{p}=0.152$ is greater than 0.05 . The control post-test data $(\mathrm{Y})$ is normally distributed. The description above shows that all research variables have a normal distribution, which is indicated by the $\mathrm{p}$-value $>0.05$.

Furthermore, in this study, the calculation of the homogeneity test uses the F test with the criteria Fcount $<$ Ftable for the degrees of freedom of the numerator db X1 = n1 - 1, and db X2 = n2 - 1, then the two variances are homogeneous. Based on the statistical analysis results between student learning interests who are taught using media Zoom Cloud Meeting and Quizizz with students who are taught using WAG media with a value of Fcount $=0.338$ with a value of $p=0.569$ $>$ 0.05, then the two data are homogeneous. When the learning was carried out, the two classes were given a different treatment, namely 4G PGSD UST class students with a total of 40 students as an experimental class who were taught using Zoom Cloud Meeting and Quizizz media and $4 \mathrm{H}$ PGSD UST class students with a total of 40 students who were taught using WAG media. Received different treatments, both groups were given a questionnaire. From the results of the questionnaire scale in both classes, a t-test was then carried out. The test results between the two variables can be seen in the following table.

Tabel 4. Results Independent TestendentTest

\begin{tabular}{|c|c|c|c|c|c|c|c|c|}
\hline & & $\mathrm{F}$ & Sig. & $\mathrm{t}$ & $\mathrm{df}$ & $\begin{array}{l}\text { Sig.(2- } \\
\text { tailed) }\end{array}$ & Mean & Std. \\
\hline \multirow[t]{2}{*}{$\begin{array}{l}\text { Interest } \\
\text { Study }\end{array}$} & $\begin{array}{l}\text { Equal } \\
\text { Variances } \\
\text { assumed }\end{array}$ & .338 & .563 & 18.376 & 78 & .000 & $\begin{array}{l}28.975 \\
\text { oo }\end{array}$ & $\begin{array}{l}1.577 \\
56\end{array}$ \\
\hline & $\begin{array}{l}\text { Equal } \\
\text { Variances } \\
\text { not } \\
\text { assumed }\end{array}$ & & & 18.376 & 77.697 & .000 & $\begin{array}{l}28.975 \\
\text { oо }\end{array}$ & $\begin{array}{l}1.577 \\
56\end{array}$ \\
\hline
\end{tabular}

Based on the t-test results, it was obtained that $\mathrm{t}$ count $=0.338$ with $\mathrm{p}$-value $=0.563$. The value then compared with a significance value of 0.05 for the one-score test, the p-value $=0.563>$ 0.05. Based on this value, Ha is accepted, meaning that there is a difference in learning interest between classes taught using Zoom Cloud Meeting and Quizizz with classes taught using WAG media. 


\section{Descriptively}

The trend of interest in learning Children's Literature 4G PGSD UST class students with a total of 40 students as an experimental class taught using Zoom Cloud Meeting and Quizizz learning media obtained an average score of 81.28 and a standard deviation of 6.831. The average value of 81.28 in the normal curve is in the very high category, with an interval between $81.28 \leq \mathrm{X}^{-}$ $\leq \overline{1}$ 8.00. Thus, the interest in learning children's literature for 4G PGSD UST class students in the experimental class who are taught using learning media Zoom Cloud Meeting, and Quizizz has a very high tendency. Media Zoom Cloud Meeting designed to conduct video conferencing-based communication which is included in the application, is classified as flexible because it can be accessed via Android, IOS and the website. This makes it easier for lecturers and students in this distance learning activity. In addition, the features presented by Zoom vary greatly so that it supports recovery. In contrast, Quizizz is a game-based educational application that is designed as attractive as possible, which is useful to help lecturers evaluate activities after college. From this description, it can be concluded that the two learning media Zoom Cloud Meeting and Quizizz, is online digital-based media that is useful for making it easier for lecturers and students to study remotely during a pandemic. So that students can carry out lectures actively and have a high interest in learning, such as lectures conducted face to face.

Meanwhile, the tendency to learn children's literature in the $4 \mathrm{H}$ PGSD UST class with 40 students as the control class using the WAG learning media obtained an average score of 51.70, and the standard deviation is 7.603. The average value in the normal curve is in the high category with an interval between $51.70 \leq \mathrm{X} 13,509$. Thus, the interest in learning Mathematics of $4 \mathrm{H}$ class students in the control class who are taught using WAG learning media has a high tendency. While the average value of the control class is 51.70 lower than the average value of the experimental class is 81.28 , with a difference of 3.32. In learning to use learning, media WAG has many obstacles that do not support it, and lecturers dominate learning activities. Students are more passive and take information from lecturers for granted, so they do not dare express their opinions to fellow students and lecturers. Thus the learning process is not optimal, and the media used in each learning activity is less varied, and as a result, students' interest in learning is low.

\section{Comparatively}

Comparative testing is used to determine how much effect the learning media is taught using Zoom Cloud Meeting and Quizizz with WAG learning media on children's literature learning interest. The analysis results of the average learning media Zoom Cloud Meeting and Quizizz 81.28 with a standard deviation value of 6.831 , while the average WAG learning media is 51.70 with a standard deviation value of 7.603. Hypothesis test results show that the price of tcount $=0.338$ with $\mathrm{p}$-value $=0.563>0.05$. Based on this value, ha failed to be rejected, meaning that there is a difference in learning interest between classes taught using learning media Zoom Cloud Meeting and Quizizz with classes taught using WAG media on children's interest in learning literature. The hypothesis test is supported by the average score of student learning interest who is taught using learning media Zoom Cloud Meeting and Quizizz 81.28. The average learning interest of students who are taught using the WAG learning media is 51.70. Based on the average score, it can be explained that the learning media Zoom Cloud Meeting and Quizizz are more effective in increasing children's interest in learning literature than WAGlearning media.

Learning through media use The use of Zoom Cloud Meetings with Quizizz is extremely beneficial for both professors and students. Because this media is intended to increase students' enthusiasm and participation in the learning process, instructors merely require students to bring their laptops or mobile phones to class in order to access media such as Zoom Cloud Meeting or Quizizz, which are both available online. Furthermore, students and lecturers must log in first before accessing the learning room, which is equipped with panels. When we turn on the camera, 
our faces will be captured on film, and when we turn on the microphone, our voices will be audible. As previously said, the use of this medium allows for greater flexibility in the lecture process. Both lecturers and students can schedule lectures at mutually agreeable times. Additionally, this medium contains useful features for lecturers, such as mute/unmute, chat, recording, and a whiteboard, among others. Quizizz, on the other hand, is no less interesting because this medium is also supplied with features that appear very much like data and statistics regarding student performance and information about which students had the lowest or greatest scores, among other things. It is possible to utilize Quizizz in the classroom directly or outside of the classroom (at home), in addition to the display of internal learning, to supplement instruction. It's also noteworthy to note that each question can be customized for the test duration and that questions can be shared with several accounts.

In contrast to lectures delivered through WAG (Whatsapp Group) media, which emphasizes one-way lectures, students are unable to freely express their opinions as they would in a traditional classroom setting. Learning is also more theoretical, with lecturers explaining more of the material, but students may not always be able to comprehend the material presented by the lecturer. As a result, lectures become more passive and repetitive, and students are unable to comprehend the subject presented clearly. Because of activities such as these, learning activities fail to progress smoothly and appear monotonous, resulting in learning activities that are solely focused on activities such as taking notes and reading material from lecturers, which causes students to become disinterested in learning in children's literature lectures.

This is in line with research by (Lukas \& Anik, 2021), who found that Zoom Cloud Meeting has a self-regulated role. This is proven when students carry out learning that students are more confident, students have a disciplined attitude, a sense of responsibility, initiative, and good selfcontrol and independence. In addition, (Ema \& Tri 2021) stated that learning during a pandemic using Zoom Cloud Meetings made students more motivated and enthusiastic; they also responded that their knowledge and learning experience became more comprehensive. Furthermore (Nita \& Sapriya, 2021) in their research, Quizizz can be used as a medium containing learning material in the form of interactive questions containing various topics and subjects made by the teacher. According to Use Quizizz improve students' abilities and motivation.

\section{CONCLUSION}

Based on the outcomes of the study, it can be concluded that using learning media such as Zoom Cloud Meeting and Quizizz during distance learning, students at the University may be more interested in taking courses in children's literature, which is a positive development. The applications Zoom Cloud Meeting and Quizizz are effective and innovative to use because they make it easier for educators (lecturers) and students to collaborate while participating in distance learning. They encourage students to develop independently slowly while keeping them up to date with new information, making them effective and innovative to use. As a result, higher education institutions, particularly the usage of e-learning media such as Zoom Cloud Meeting and Quizizz, will be incredibly necessary and vital in the future in order to develop and follow the progress of a more modern period. 


\section{REFERENCES}

Belawati, T. (2019). Online Learning. Tangerang: Open University.

Ema , E., \& Tri, Y. A. (2021). Students' Perspective: Virtual-Based Learning amid the Covid-19 Pandemic by Pre-Service Teachers in Rural Area, Thailand. Journal of English Teaching, Literature, and Applied Linguistics Vol. 5, No. 1, 46-53. http://dx.doi.org/10.30587/jetlal.v5i1.2157.

Harefa, N. (2021). Trends in Students' Interest in Learning Chemistry Against Online Learning During the Covid-19 Pandemic. In: Proceeding Of The National Science Seminar XI "Science Learning Innovation with Environmental Insight in a Pandemic Period". Semarang: LPPM UNNES.

Inga, B., Anne, P., \& Momoko, K. (2021). Building a resilient university: ensuring academic. WMU Journal of Maritime Affairs (2021), 151-172. https://doi.org/10.1007/s13437-021-00239$\mathrm{X}$.

Irawati, S. e. (2020). Application of Structured Inquiry Learning Model to Improve Student Learning Outcomes Class Viib Mtsn 02 Kepahiang. Diklabio: Journal of Biology Education and Learning , 55-64. https://doi.org/10.33369/diklabio.4.1.47-54.

Kasman , \& Zohri , H. (2021). The effect of zoom app towards students' interest in learning on online learning. Dinasti international journal of education management and social science, Vol 2, No.3., 404-408. https://doi.org/10.31933/dijemss.v2i3.752.

Leony, S. L. (2019). Increasing Student Learning Concentration Through Utilization of Quizizz Learning Evaluation in Physical Chemistry I Course. JDP Vol. 12 No. 33, 33. http://ejournal.uki.ac.id/index.php/jdp/index.

Liu, I. (2020). The Effect of Zoom Cloud Meeting-based Online Learning on Learning Outcomes of Physics Students at the University of Flores. Journal of Physics and Scientific Education (JPFK), 34.http://doi.org/10.25273/jpfk.v6i1.7303.

Lukas , G. A., \& Anik , G. (2021). The Implementation of Zoom Cloud Meeting on Choir Learning in the Covid-19 Pandemic. (pp. 6-13. ). Atlantis Press SARL. http://creativecommons.org/licenses/by-nc/4.0/.

Marsye , F. (2021). Perception Of Basic Training Participants To The Use Of Quizizz As A Learning Evaluation Method. Akademika : Jurnal Teknologi Pendidikan, 10(O1), 163-178. https://doi.org/10.34005/akademika.v10io1.1228.

Muhammad , N. (2021). Fostering Success and Motivating EFL Learners Using Zoom Meeting: A Synchronous Learning Strategy. Anglophile Journal, Vol. 1, No. 2. , 1-12. https://dx.doi.org/10.51278/anglophile.v1i2.174.

Muhhibin, S. (2008). In Educational Psychology (p. 65). Bandung: Remaja Rosdayakara.

Nashar, Nurhasanah, A., \& Fauzan, R. (2021). The Effectiveness of Critical Thinking Ability on the Basis of Quizizz Application Viewed from Problem Based Learning Model in History Learning of Senior High School. IOP Conference Series: Earth and Environmental Science. , 1-8. doi:10.1088/1755-1315/747/1/012046.

Nita, D., \& Sapriya. (2021). The Role of Media Quizizz in CivicsLearning to Increase Learning Motivation for Elementary School Students. The 3rd International Conference on Elementary Education, 3(1), (pp. 194-198). Bandung: Universitas Pendidikan Indonesia.

Nurrohmatul , A., \& Luluk , R. H. (2021). The Use of Application Namely Quizizz in Elementary School Students' Outcomes. Proceedings of the 1st Annual International Conference on Natural and Social Science Education (ICNSSE 2020), Vol. 547., 42-48. http://creativecommons.org/licenses/by-nc/4.0/.

Olena , K., \& Oksana , D. (2020). Overcoming the Challenges the Impact of COVID-19 on Agricultural Higher Education in Ukraine. Revista Românească pentru Educaţie 


$\begin{array}{lllllll}\text { Multidimensională volume } \quad 12, & \text { Issue } & 2, & \text { Sup. } & 1,, & 162-167 .\end{array}$
https://doi.org/10.18662/rrem/12.2Sup1/302.

Prima, L., \& Fitri , N. (2021). Mathematics Learning Using Zoom Cloud Meeting During the Covid19 Pandemic for Elementary School Students. Pedagogik Journal of Islamic Elementary School, Vol.4, No.1., 45-58. https://doi.org/10.24256/pijies.v4i1.1776.

Rani , K., \& Ernawulan, S. (2021). The Utilization of Quizizz Learning Media for Learning Basic Education. The 3rd International Conference on Elementary Education, 3(1). , 112-118. http://proceedings2.upi.edu/index.php/icee/article/view/1451\#: :text=http\%3A//proceed ings2.upi.edu/index.php/icee/article/view/1451.

Sardiman, A. (2003). Teaching and Learning Interaction and Motivation. Jakarta: PT Raja Grafindo Persada.

Serikbayeva , U., \& Erzhanova , Z. (2021). Using The Zoom Service In Distance Learning. International Journal of Educational and Scientific Research No.4 (12)., 29-32. https://doi.org/10.31219/osf.io/5qzgm.

Shaid, M., Tasaddaq, H., Abdul, G., \& Kiran, S. (2021). Exploring Students Online Learning: A Study Of Zoom Application. Journal of Science, GU J Sci 34 (o2). , 172-178. https://doi/10.35378/gujs.691705.

Simamora, R. (2020). The Challenges of Online Learning during the COVID-19 Pandemic: An Essay Analysis of Performing Arts Education Students. Jurnal Studies in Learning and Teaching Vol.1, No.2., 86-103. https://doi.org/10.46627/silet.v1i2.38.

Slameto. (2010). Learming and the factors that influence it. Jakarta: Rineka Cipta.

Sri , H., Sri , W., Dedi, F., \& Anggi , D. (2021). The Development of Evaluation Instruments in Online Learning using the Quizizz Application: During Covid-19 Pandemic. Al-Ishlah: Jurnal Pendidikan, Vol.13(1)., 364-373. DOI:10.35445/alishlah.v13i1. 383.

Suardi , M. (2020). The Effectiveness of Using the Zoom Cloud Meetings Application in the Learning Process. Proceeding of The International Conference on Science and Advanced Technology (ICSAT) (pp. 590-602). Makasar : Universita Negeri Makasar.

Trully , Y. P., \& Ganefri . (2020.). Development of Quizizz-based Learning Media on Basic Computer and Network Subjects. Indonesian Journal Of Educational Research And Review, Volume 3, No.3., 106-112. http://dx.doi.org/10.23887/ijerr.v3i3.30949.

Wahyu, A., \& Simanullang, R. (2020). Student Stress Due to Online Learning During the Covid-19 Pandemic. Jurnal Aisyah: Jurnal Ilmu Kesehatan, 5(2), 153-157. https://doi.org/10.30604/jika.v5i2.346.

Wandi , K. (2021). The effectiveness of the zoom meeting application on the quality of distance learning for community education students at IKIP Siliwangi Class 2018. Comm-Edu (Community Education Journal), 4(2)., 76-81. http://dx.doi.org/10.2246o/commedu.v4i2.7201.

Zhang, R. e., Yixin, L., Annie , L., Yuan, W., \& Mario , J. (2020). Identifying airbone transmission as the dominate route for the spread of COVID-19. PNAS, 117, 14857-14863. https://doi.org/10.1073/pnas.2009637117. 